\title{
Endoplasmic reticulum stress sensitizes pancreatic beta cells to interleukin-1 $\beta$-induced apoptosis via Bim/A1 imbalance
}

\author{
M Miani ${ }^{1}$, J Barthson ${ }^{1}$, ML Colli $^{1}, \mathrm{~F}$ Brozzi $^{1}$, M Cnop $^{1,2}$ and DL Eizirik ${ }^{\star, 1}$
}

We have recently shown that the crosstalk between mild endoplasmic reticulum (ER) stress and low concentrations of the pro-inflammatory cytokine interleukin (IL)-1 $\beta$ exacerbates beta cell inflammatory responses via the IRE1 $\alpha / X B P 1$ pathway. We presently investigated whether mild ER stress also sensitizes beta cells to cytokine-induced apoptosis. Cyclopiazonic acid (CPA)-induced ER stress enhanced the IL-1 $\beta$ apoptosis in INS-1E and primary rat beta cells. This was not prevented by XBP1 knockdown (KD), indicating the dissociation between the pathways leading to inflammation and cell death. Analysis of the role of pro- and anti-apoptotic proteins in cytokine-induced apoptosis indicated a central role for the pro-apoptotic BH3 (Bcl-2 homology 3)-only protein Bim (Bcl-2-interacting mediator of cell death), which was counteracted by four anti-apoptotic Bcl-2 (B-cell lymphoma-2) proteins, namely Bcl-2, Bcl-XL, Mcl-1 and A1. CPA + IL-1 $\beta$-induced beta cell apoptosis was accompanied by increased expression of Bim, particularly the most pro-apoptotic variant, small isoform of $B i m\left(B i m_{S}\right)$, and decreased expression of A1. Bim silencing protected against CPA + IL-1 $\beta$-induced apoptosis, whereas A1 KD aggravated cell death. Bim inhibition protected against cell death caused by A1 silencing under all conditions studied. In conclusion, mild ER stress predisposes beta cells to the pro-apoptotic effects of IL-1 $\beta$ by disrupting the balance between pro- and anti-apoptotic Bcl-2 proteins. These findings link ER stress to exacerbated apoptosis during islet inflammation and provide potential mechanistic targets for beta cell protection, namely downregulation of Bim and upregulation of $\mathbf{A} 1$.

Cell Death and Disease (2013) 4, e701; doi:10.1038/cddis.2013.236; published online 4 July 2013

Subject Category: Experimental Medicine

Type 1 diabetes (T1D) is a chronic autoimmune disease, characterized by islet inflammation (insulitis) and progressive immune-mediated apoptosis of pancreatic beta cells via local production of pro-inflammatory cytokines, activation of FasLFas and other mechanisms. ${ }^{1,2}$ The incidence of T1D is rising worldwide, especially among the youngest generation. ${ }^{3,4}$ This rapid augmentation in T1D incidence suggests an increased environmental pressure upon individuals with genetic predisposition to the disease. ${ }^{5,6}$ We hypothesized that the induction of beta cell endoplasmic reticulum (ER) stress by obesityinduced insulin resistance and/or by other mechanisms such as viral infections or other environmental insults that remain to be elucidated may contribute to the pathogenesis of T1D. ${ }^{7,8}$

When faced with compromised ER homeostasis and ER stress, cells trigger the unfolded protein response (UPR) through activation of three ER transmembrane proteins: activating transcription factor-6 (ATF-6), inositol-requiring enzyme $1 \alpha(\operatorname{IRE} 1 \alpha)$ and RNA-activated protein kinase-like eukaryotic initiation factor $2 \alpha$ kinase (PERK).$^{7,9-11}$ The UPR attenuates the protein load on the ER by decreasing global protein synthesis in parallel to increasing translation of ER chaperones and foldases involved in correct protein maturation; terminally misfolded proteins are degraded. If the stress cannot be resolved, the UPR triggers apoptosis. 9,10,12,13

The UPR crosstalks with other pathways, particularly inflammation, ${ }^{8}$ while on the other hand inflammation may elicit ER stress. The pro-inflammatory cytokines interleukin-1$\beta$ (IL-1 $\beta$ ), tumor necrosis factor- $\alpha$ (TNF- $\alpha$ ) and interferon- $\gamma$ $(\mathrm{IFN}-\gamma)$ induce ER stress in vitro in rodent and human beta cells. ${ }^{14-16}$ Islets from prediabetic, nonobese diabetic mice have increased expression of ER-stress markers and activation of the pro-inflammatory transcription factor nuclear factor $\kappa-\mathrm{B}(\mathrm{NF}-\kappa \mathrm{B}),{ }^{17}$ whereas islets from T1D patients show increased expression of the UPR markers C/EBP homologous protein (CHOP) and $\mathrm{BiP}$, but not $\mathrm{X}$-box-binding protein-1 (XBP1). ${ }^{18}$ We have recently shown that mild ER

\footnotetext{
${ }^{1}$ Laboratory of Experimental Medicine, Université Libre de Bruxelles (ULB), Brussels, Belgium and ${ }^{2}$ Division of Endocrinology, Erasmus Hospital, Université Libre de Bruxelles, Brussels, Belgium

${ }^{*}$ Corresponding author: DL Eizirik, Laboratory of Experimental Medicine, Université Libre de Bruxelles (ULB), Route de Lennik, 808-CP618, Brussels B-1070, Belgium. Tel: + 322555 6242; Fax: + 322555 6239; E-mail: deizirik@ulb.ac.be

Keywords: type 1 diabetes; pancreatic beta cells; endoplasmic reticulum stress; apoptosis; Bim; A1

Abbreviations: A1 (also known as Bcl-2A1), B-cell lymphoma-2 A1; ATF-6, activating transcription factor-6; Bak, Bcl-2 antagonist/killer; Bax, Bcl-2-associated X protein; Bcl, B-cell lymphoma; BH3, Bcl-2 homology 3; Bim, Bcl-2-interacting mediator of cell death; CHOP, C/EBP homologous protein; CPA, cyclopiazonic acid; DMSO, dimethylsulfoxide; DP5, death protein 5; ER, endoplasmic reticulum; FBS, fetal bovine serum; IL-1 $\beta$, interleukin-1 $\beta$; IRE1 $\alpha$, inositol-requiring enzyme 1; IFN- $\gamma$, interferon- $\gamma$; GAPDH, glyceraldehyde-3-phosphate dehydrogenase; KD, knockdown; Mcl-1, myeloid cell leukemia sequence-1; NF- $\kappa \mathrm{B}$, nuclear factor $\kappa \mathrm{B}$; PERK, RNA-activated protein kinase-like eukaryotic initiation factor $2 \alpha$ kinase; PI, propidium iodide; PUMA, p53-upregulated modulator of apoptosis; siRNA, small interfering RNA; T1D, type 1 diabetes; TNF- $\alpha$, tumor necrosis factor- $\alpha$; TXNIP, thioredoxin-interacting protein; UPR, unfolded protein response; UT, untreated; XBP1, X-box-binding protein 1
}

Received 12.3.13; revised 10.5.13; accepted 29.5.13; Edited by M Federici 
stress sensitizes pancreatic beta cells to the pro-inflammatory effects of the cytokine IL- $1 \beta$ via enhanced NF- $k$ B activation, ${ }^{19}$ leading to augmented chemokine and Fas expression levels. A detailed study of the three UPR branches identified the IRE1 $\alpha /$ XBP1s (XBP1-spliced) pathway as being responsible for this amplified pro-inflammatory response..$^{19}$

Protracted or excessive ER stress and pro-inflammatory cytokines trigger beta cell death through the 'mitochondrial' or intrinsic pathway of apoptosis. This pathway is regulated by the $\mathrm{Bcl}-2$ (B-cell lymphoma-2) protein family, which includes pro- (such as the Bcl-2 homology 3 (BH3)-only proteins) and anti-apoptotic proteins. ${ }^{12,20,21}$ Recent studies suggest that death protein 5 (DP5, also known as Harakiri), ${ }^{22}$ p53-upregulated modulator of apoptosis (PUMA) ${ }^{23}$ and Bcl-2-interacting mediator of cell death $(\mathrm{Bim})^{21,24-26}$ are the key pro-apoptotic BH3-only proteins in cytokine-treated beta cells, whereas relevant anti-apoptotic proteins include $\mathrm{Bcl}-2$, $\mathrm{Bcl}-\mathrm{XL}$, myeloid cell leukemia sequence-1 (Mcl-1) and $\mathrm{A} 1$ (also known as Bcl-2A1). ${ }^{23,25,27,28}$ It remains to be defined, however, how the balance between these proteins regulates the activation of $\mathrm{Bcl}-2$-associated $\mathrm{X}$ protein (Bax) and $\mathrm{Bcl}-2$ antagonist/killer (Bak), the consequent activation of caspases 9 and 3 , and the execution of beta cell apoptosis. ${ }^{12}$

Triggering of beta cell apoptosis is the ultimate mechanism regulating the transition from insulitis to clinical diabetes. Here, we studied the mechanisms implicated in the crosstalk between the UPR and inflammatory signals that lead to beta cell apoptosis. For this purpose, beta cells were exposed to a mild ER stress induced by the chemical stressor cyclopiazonic acid (CPA; $6.25 \mu \mathrm{M})$ and then cultured in the presence of a low dose of the cytokine $\mathrm{IL}-1 \beta(0.5 \mathrm{U} / \mathrm{ml}$; this concentration was selected based on dose-response studies as the lowest concentration that induces $\mathrm{NF}-\kappa \mathrm{B}$ activation ${ }^{19}$ ). At the selected concentration, CPA induces a $2-5$-fold increase in the expression of $\mathrm{CHOP}, \mathrm{XBP} 1 \mathrm{~s}$ and $\mathrm{BiP}$, with only mild $(<10 \%)$ apoptosis $^{29}$ or insulin mRNA degradation (see below). After determining that CPA + IL-1 $\beta$ treatment exacerbates apoptosis, we performed a detailed mechanistic analysis of the ER stress pathways and $\mathrm{Bcl}-2$ proteins involved in cytokine- and/or ER stress + cytokine-induced beta cell apoptosis. This allowed us to reach three main conclusions: (1) Bim is the central pro-apoptotic BH3-only protein in the context of inflammation-induced beta cell apoptosis; (2) ER stress + inflammation-induced beta cell apoptosis is triggered by an imbalance between the pro-apoptotic protein Bim and the anti-apoptotic protein A1; (3) there are different molecular mechanisms underlying the potentiation by ER stress of cytokine-induced inflammation ${ }^{19}$ and beta cell death (present data).

\section{Results}

ER stress enhances IL-1 $\beta$-induced beta cell apoptosis in a XBP1-independent manner. A dose-response analysis of ER stress in CPA-treated INS-1E cells indicated that $6.25 \mu \mathrm{M}$ clearly induces the expression of XBP1s and $\mathrm{CHOP}$, but not degradation of Ins-2 mRNA, which is an indicator of severe ER stress ${ }^{30}$ (Supplementary Figure 1); similar observations were obtained at later time points ${ }^{19,29}$ and data not shown). Based on these results, 6.25 $\mu \mathrm{M}$ CPA was selected for subsequent experiments aiming to induce a mild ER stress. A time-course analysis of beta cell apoptosis in INS-1E cells after a $6 \mathrm{~h}$ CPA treatment followed by exposure to IL-1 $\beta$ (Figure 1a) indicated that IL-1 $\beta$ alone did not induce beta cell apoptosis at any time point analyzed, whereas CPA increased cell death in a time-dependent manner. The CPA pretreatment sensitized cells to $\mathrm{IL}-1 \beta$, aggravating cell death both in INS-1E (Figure 1a) and primary rat beta cells (Figure 1b). These findings were confirmed by protein analysis of cleaved caspases 9 and 3 (Figures 1c-e), indicating a clear increase in caspase activation with $\mathrm{CPA}+\mathrm{IL}-1 \beta$ as compared with either agent alone, and confirming that apoptosis takes place via the intrinsic mitochondrial pathway. ${ }^{12}$

Previous results from our group ${ }^{19}$ indicated that ER stress crosstalks with the NF- $\kappa$ B pathway via XBP1s, leading to an enhanced pro-inflammatory response. To examine whether the same pathway was responsible for the observed increase in cell death, we silenced XBP1 and treated cells with CPA for $6 \mathrm{~h}$, followed by IL-1 $\beta$ for $24 \mathrm{~h}$. XBP1 knockdown (KD, Figure 2a) augmented apoptosis and did not protect against cell death under the ER stress \pm cytokine conditions (Figure 2b), suggesting different mechanisms for UPRinduced inflammation and apoptosis.

A1 and $\mathrm{Mcl}-1$ inhibition sensitizes to cytokine-induced Bim-mediated apoptosis. We next examined which components of the intrinsic pathway are relevant for cytokineinduced beta cell apoptosis. In a well-described model of apoptosis induced by two cytokines, namely $\mathrm{IL}-1 \beta$ and IFN- $\gamma,{ }^{12,31}$ we assessed the role of the anti-apoptotic proteins A1, Bcl-2, Bcl-XL and $\mathrm{Mcl}-1$. An early time point (8h) was selected for these experiments, as KD of some of the anti-apoptotic Bcl-2 proteins led to massive cell death after 16-24h, rendering data interpretation difficult (data not shown). The KD of each single Bcl-2 anti-apoptotic protein (confirmed in Supplementary Figure 2) increased apoptosis under basal conditions (Figure 3). KD of A1 and Mcl-1, but not of $\mathrm{Bcl}-2$ and $\mathrm{Bcl}-\mathrm{XL}$, sensitized beta cells to cytokine-induced apoptosis. Concomitant KD of the pro-apoptotic protein Bim protected against apoptosis when A1 (Figure 3a), Bcl-2 (Figure $3 b$ ) or Mcl-1 (Figure $3 d$ ) were inhibited. In the case of $\mathrm{Bcl}-\mathrm{XL}$, this protection was only partial (Figure $3 \mathrm{c}$ ). In additional experiments, we extended the observations with A1 and/or Bim KD to $16 \mathrm{~h}$ (Supplementary Figure 3), observing again the sensitization to basal and cytokine-induced cell death by $\mathrm{A} 1 \mathrm{KD}$, and full protection by Bim KD.

A1 degradation and $\mathrm{Bim}_{\mathrm{S}}$ (small isoform of Bim) induction are central to the enhancement of IL-1 $\boldsymbol{\beta}$-induced beta cell apoptosis by ER stress. In addition to the central role of Bim in cytokine-induced apoptosis (Figure 3 and Supplementary Figure 3), inhibition of Bim (Figures 4a and c) abrogated the sensitization of both INS-1E cells (Figure $4 b$ ) and primary rat beta cells (Figure $4 d$ ) by ER stress to IL-1 $\beta$-induced cell death. Under the same experimental conditions, there was no significant increase in DP5 expression and a nonsignificant trend for higher PUMA expression (data not shown); PUMA KD, however, failed to protect against CPA $+\mathrm{IL}-1 \beta$-induced cell death (data not 

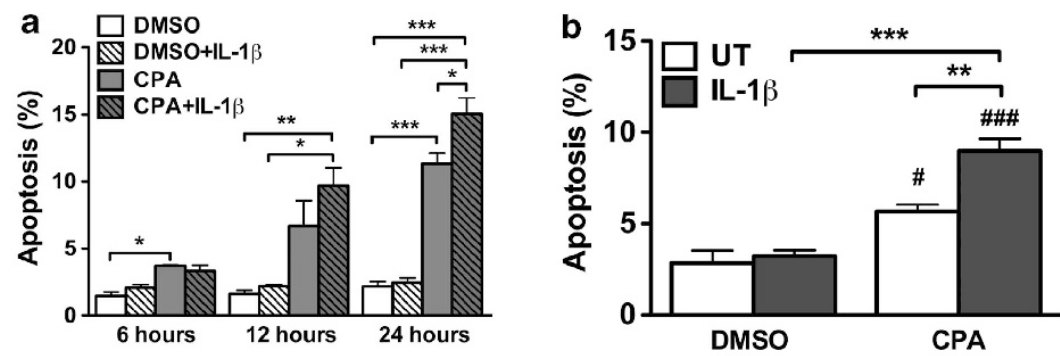

C
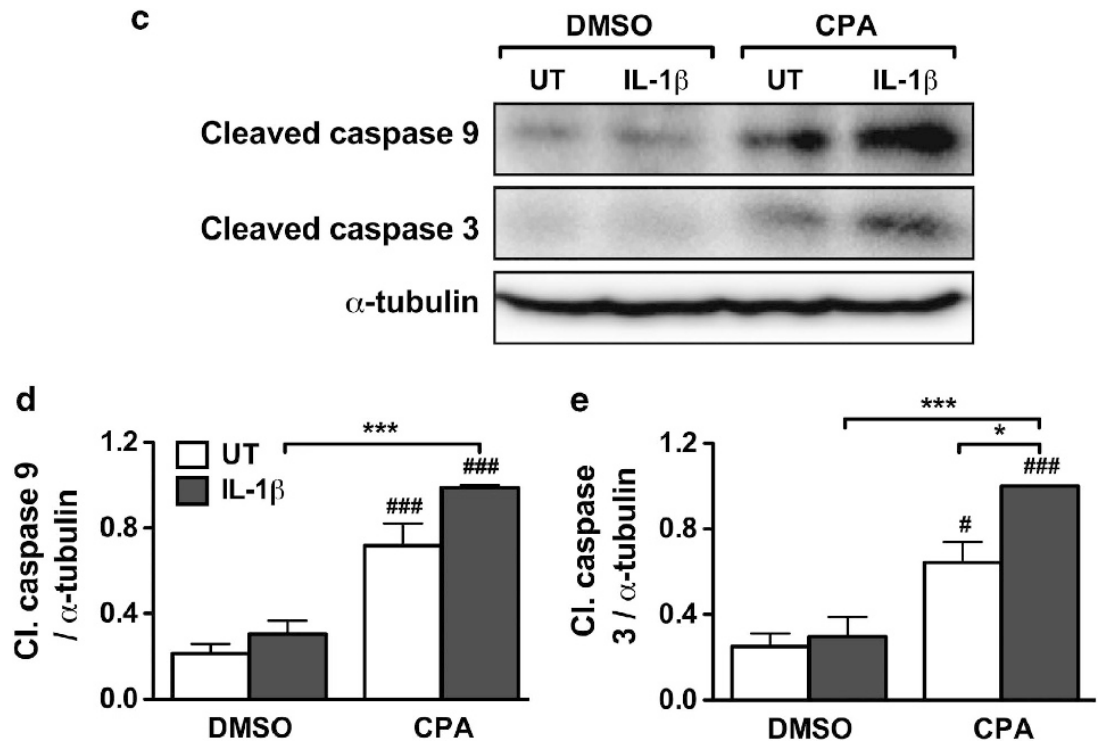

Figure 1 CPA pretreatment sensitizes beta cells to IL-1 $\beta$-induced beta cell apoptosis. (a) INS-1E cells were exposed to CPA (6.25 $\mu \mathrm{M})$ or DMSO for $6 \mathrm{~h}$ and then treated or not with IL- $1 \beta(0.5 \mathrm{U} / \mathrm{ml})$ for the indicated time points. Apoptosis was evaluated by Hoechst $33342 / \mathrm{PI}$ staining. Results are the mean of three to six experiments, ${ }^{*} P<0.05$, ${ }^{* *} P<0.01$ and ${ }^{* * *} P<0.001$ versus indicated bars, ANOVA. (b) Primary rat beta cells were treated as in (a) $(6 \mathrm{~h}$ of CPA followed or not by $24 \mathrm{~h}$ with IL-1 $\beta)$. Apoptosis was evaluated by Hoechst $33342 / \mathrm{PI}$ staining. Results are the mean of four independent experiments. ${ }^{\#} P<0.05$ and ${ }^{\# \# \#} P<0.001$ versus DMSO (UT), ${ }^{*} P<0.05$ versus indicated bars, ANOVA. (c) INS-1E cells treated as in (a) were harvested and analyzed by western blot. A representative picture of cleaved caspases 9 and 3 is shown. (d and $\mathbf{e}$ ) western blots of caspases 9 and 3 , respectively, were quantified by densitometry. Results are the mean \pm S.E.M. of four independent experiments. UT denotes untreated. ${ }^{\#} P<0.05$ and ${ }^{\# \# \#} P<0.001$ versus DMSO, ${ }^{*} P<0.05$ and ${ }^{* * \star} P<0.001$ versus indicated bars, ANOVA

shown). To further study the role of Bim in CPA + IL-1 $\beta$-induced apoptosis, we analyzed by western blot its expression after $6 \mathrm{~h}$ of pretreatment with CPA, followed by a $24 \mathrm{~h} \mathrm{IL-1} \beta$ exposure (Figure $5 \mathrm{a}$ ). The quantification of Bim isoforms revealed that the most pro-apoptotic variant $\mathrm{Bim}_{\mathrm{s}}{ }^{32}$ is 2.9-fold upregulated (Figure $5 \mathrm{~d}$ ), compared with a small increase $(40 \%)$ in the isoforms Bim $\mathrm{EL}_{\mathrm{L}}$ (Figure $5 \mathrm{~b}$ ) and Bim $\mathrm{L}$ (Figure 5c).

Beta cell apoptosis depends on the balance between pro- and anti-apoptotic $\mathrm{Bcl}-2$ proteins. ${ }^{12}$ Our previous findings indicated that cytokines and ER stress inhibit the anti-apoptotic proteins $\mathrm{Bcl}-\mathrm{XL}^{21,23}$ and $\mathrm{Mcl}-1 .{ }^{27} \mathrm{~A} 1$ was recently described by our group to be present in human and rodent beta cells. ${ }^{28}$

Beta cell apoptosis was evaluated after A1 (Figure 6a) and/ or Bim (Figure 6b) KD. As observed for cytokine treatment (Figure 3a), A1 KD increased apoptosis in both untreated and treated (CPA and CPA + IL-1 $\beta$ ) conditions (Figure 6c). Inhibition of Bim protected beta cells from apoptosis induced by $\mathrm{CPA}+\mathrm{IL}-1 \beta$ and $\mathrm{A} 1 \mathrm{KD}$.

It was previously shown that cytokines cause $\mathrm{Mcl}-1$ degradation, ${ }^{27}$ contributing to beta cell apoptosis. We thus performed a time-course study to determine whether A1 protein expression is similarly affected after IL- $1 \beta+\mathrm{IFN}-\gamma$ exposure or CPA $(6 \mathrm{~h})+\mathrm{IL}-1 \beta$ (12 or $24 \mathrm{~h}$ ) treatment. This analysis indicated that $\mathrm{A} 1$ is induced by IL- $1 \beta+\mathrm{IFN}-\gamma$ at $2 \mathrm{~h}$, but returns to the basal level after a $24 \mathrm{~h}$ treatment (Figure 7a). $\mathrm{CPA} \pm \mathrm{IL}-1 \beta$ exposure progressively decreased A1 expression, reaching a nadir at $24 \mathrm{~h}$ (Figures $7 \mathrm{~b}$ and c). Collectively, these results demonstrate that ER stress induces beta cell sensitivity to IL-1 $\beta$ by degrading the anti-apoptotic Bcl-2 protein $A 1$ and by increasing the expression of the highly proapoptotic Bims isoform.

\section{Discussion}

We presently describe that mild ER stress sensitizes pancreatic beta cells to the pro-apoptotic effects of the cytokine IL-1 $\beta$ by altering the balance between the antiapoptotic Bcl-2 protein A1 and the pro-apoptotic BH3-only protein Bim.

The clinical manifestations of T1D represent the end stage of a chronic autoimmune process characterized by insulitis and progressive beta cell apoptosis. ${ }^{1,12}$ The preclinical stage 

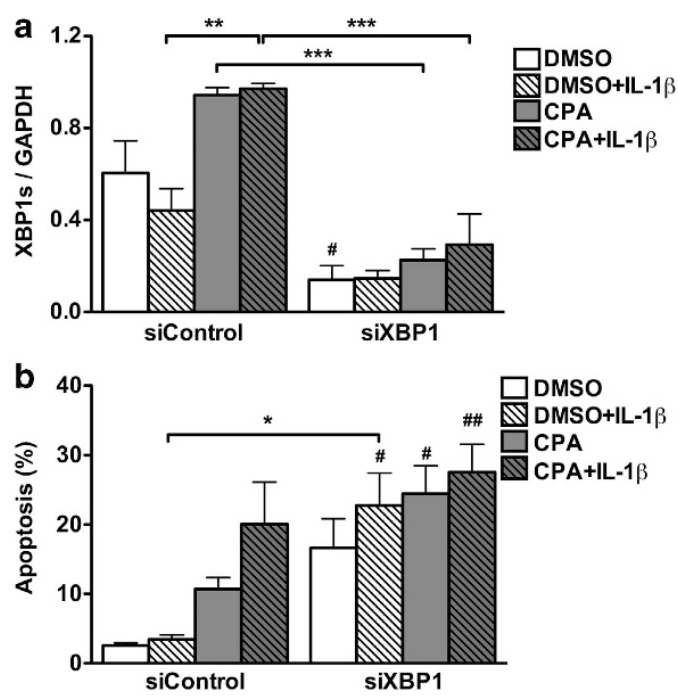

Figure $2 \mathrm{KD}$ of XBP1 does not prevent CPA + IL-1 $\beta$-induced beta cell apoptosis. INS-1E cells were transfected with a siRNA against XBP1 (siXBP1) or with a negative control siRNA (siControl). After $48 \mathrm{~h}$, cells were exposed to CPA $(6.25 \mu \mathrm{M})$ or DMSO for $6 \mathrm{~h}$ and then treated with IL-1 $\beta(0.5 \mathrm{U} / \mathrm{ml})$ or left untreated for $24 \mathrm{~h}$. (a) Cells were harvested to determine the mRNA expression of XBP1s and the housekeeping gene GAPDH. (b) Beta cell apoptosis was evaluated by Hoechst $33342 / \mathrm{PI}$ staining. Results are the mean \pm S.E.M. of four independent experiments. ${ }^{\#} P<0.05$ and ${ }^{\# \#} P<0.01$ versus siControl + DMSO, ${ }^{\star} P<0.05, \quad{ }^{* \star} P<0.01$ ${ }^{* * *} P<0.001$ versus indicated bars, ANOVA

is silent and may last for years. ${ }^{2}$ It is conceivable that during this period nonimmunologic factors, such as ER stress in beta cells, accelerate local inflammation and beta cell loss. ${ }^{8}$ ER stress may be induced by obesity and insulin resistance (through the augmented demand placed on the pancreatic beta cells and/or via increased levels of circulating fatty acids), by viral infections or by other environmental insults that remain to be clarified. ${ }^{7}$ In the diabetes-prone BioBreeding rat, an animal model of T1D, increasing the plasma-free fatty acid levels by two-fold significantly impaired beta cell function and augmented islet cytokine levels. ${ }^{33}$

We have recently shown that CPA-induced ER stress and IL-1 $\beta$ potentiate the pro-inflammatory response of beta cells, characterized by increased expression of chemokines and Fas, via activation of the transcription factor NF- $\kappa$ B by the IRE1 $\alpha /$ XBP1 branch of the UPR..$^{19}$ XBP1 silencing, however, did not protect beta cells against the increased apoptosis induced by CPA + IL-1 $\beta$ (present data), indicating that the pro-inflammatory and pro-apoptotic effects of ER stress are mediated by different pathways. Recent findings indicate that thioredoxin-interacting protein (TXNIP) is induced by ER stress and contributes to sterile inflammation and UPRdependent beta cell apoptosis. ${ }^{34,35}$ In our experimental model, TXNIP was induced by CPA treatment, but its expression was not enhanced by the addition of IL-1 $\beta$ (data not shown), suggesting that other mechanisms explain beta cell apoptosis caused by mild ER stress plus IL- $1 \beta$.

Our previous findings, ${ }^{21,24-26}$ together with the present detailed analysis of the role of pro- and anti-apoptotic $\mathrm{Bcl}-2$ proteins in basal or cytokine-induced apoptosis, indicate that Bim is a central mediator of beta cell death (Figure 3). Importantly, the presence of four anti-apoptotic proteins,
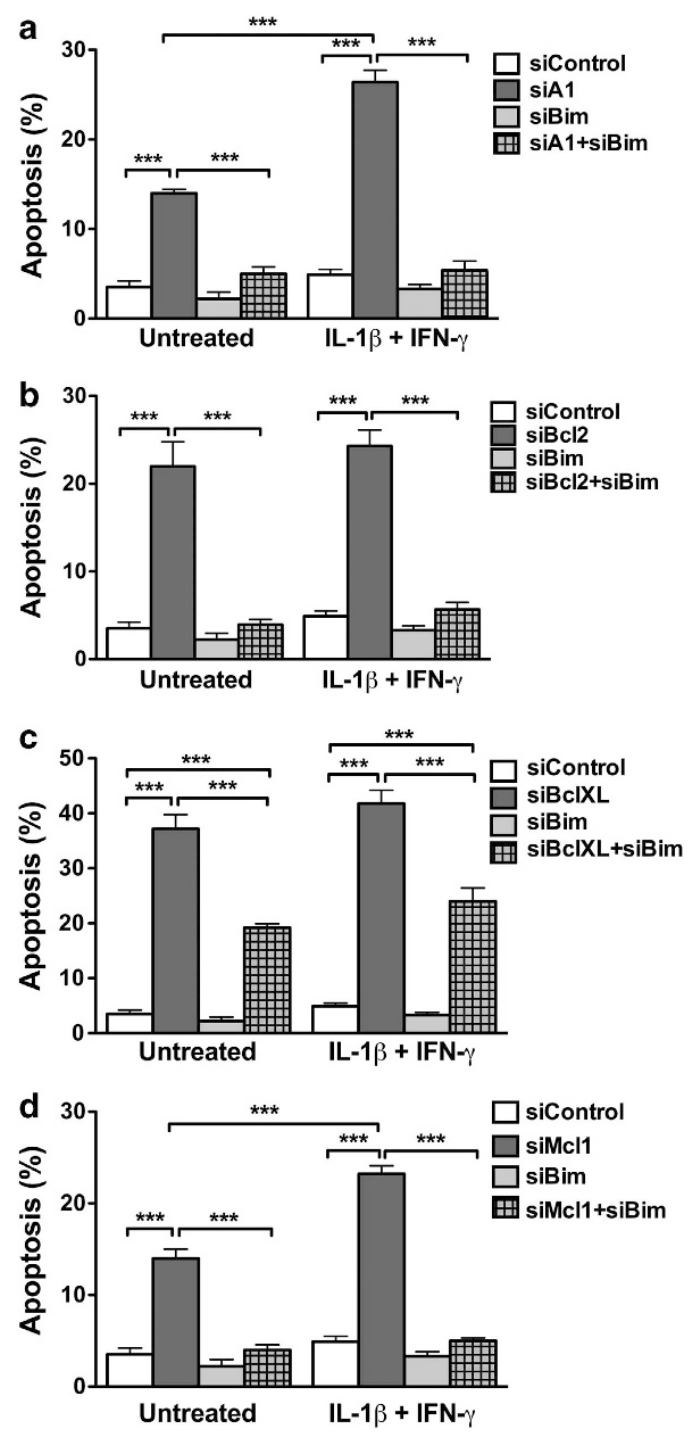

Figure 3 Bim KD protects against beta cell apoptosis induced by inactivation of $\mathrm{Bcl}-2$ proteins and/or cytokine treatment. INS-1E cells were transfected with siRNAs against $\mathrm{A} 1$ (siA1, panel a), Bcl-2 (siBcl2, panel b), Bcl-XL (siBclXL, panel c), Mcl-1 (siMcl1, panel d) alone or together with siRNA against Bim (siBim) or with a negative control siRNA (siControl). After $48 \mathrm{~h}$, cells were treated with IL- $1 \beta+\mathrm{IFN}-\gamma$ (10 and $100 \mathrm{U} / \mathrm{ml}$, respectively) for $8 \mathrm{~h}$ or left untreated. Beta cell apoptosis was evaluated by Hoechst $33342 / \mathrm{PI}$ staining. Results are the mean \pm S.E.M. of five independent experiments. ${ }^{* *} P<0.001$ versus indicated bars, ANOVA

namely A1, Bcl-2, Bcl-XL and Mcl-1, is necessary to counteract the pro-apoptotic effects of Bim. Although Bim KD abrogated the increase in cell death observed after KD of $\mathrm{A} 1, \mathrm{BCl}-2$ or $\mathrm{Mcl}-1$, the protective effect observed following $\mathrm{Bcl}-\mathrm{XL}$ inhibition was only partial. Bcl-XL counteracts the effects of both Bim and PUMA in beta cells, ${ }^{21,23}$ and it is conceivable that the residual cell death observed following $\mathrm{Bim}$ and $\mathrm{Bcl}-\mathrm{XL}$ KD is PUMA-dependent. Furthermore, Bcl-XL induces the retrotranslocation of Bax from the mitochondrial outer membrane to the cytoplasm, acting very early in the multistep Bax activation. ${ }^{36}$ Thus, Bcl-XL inhibition may predispose cells to death in a broad way that cannot be prevented by the simultaneous $\mathrm{KD}$ of a single $\mathrm{BH} 3-$ only protein. 


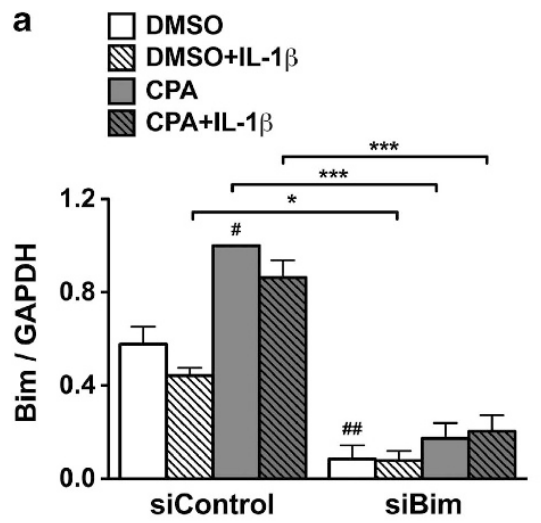

c

b

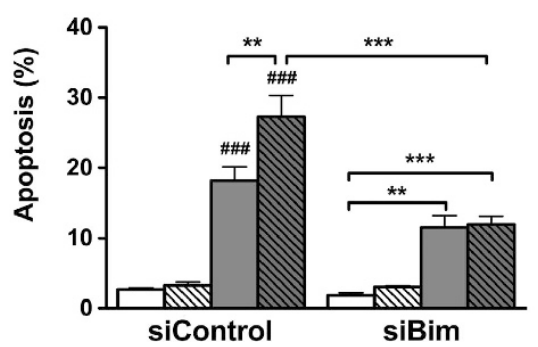

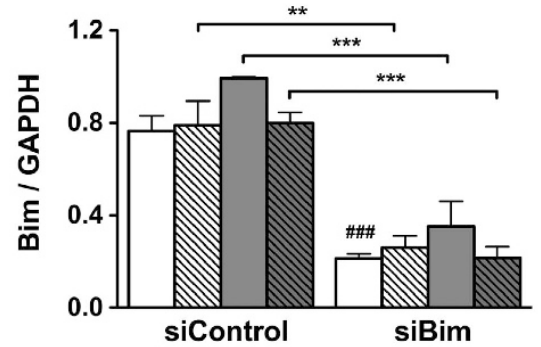

d

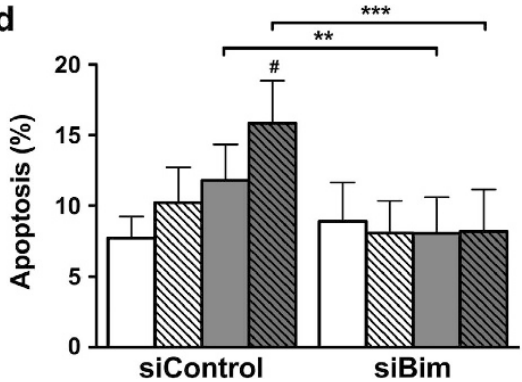

Figure 4 Bim KD protects against CPA + IL-1 $\beta$-induced beta cell apoptosis in INS-1E and primary beta cells. INS-1E cells and primary rat beta cells were transfected with siRNA against Bim (siBim) or with negative control siRNA (siControl). After $48 \mathrm{~h}$, cells were exposed to CPA $(6.25 \mu \mathrm{M})$ or DMSO for $6 \mathrm{~h}$ and then treated or not with IL-1 $\beta$ $(0.5 \mathrm{U} / \mathrm{ml})$ for $24 \mathrm{~h}$. INS-1E and primary beta cells (a and $\mathbf{c}$, respectively) were harvested for determination of mRNA expression of Bim and the housekeeping gene GAPDH. Beta cell apoptosis was evaluated in INS-1E and primary beta cells ( $b$ and $\mathbf{d}$, respectively) by Hoechst 33342/PI staining. Results are the mean \pm S.E.M. of four independent experiments. ${ }^{\#} P<0.05,{ }^{\# \#} P<0.01$ and ${ }^{\# \# \#} P<0.001$ versus siControl + DMSO, ${ }^{*} P<0.05,{ }^{\star *} P<0.01$ and ${ }^{* * *} P<0.001$ versus indicated bars; ANOVA

Bim has a key role for ER stress plus $\mathrm{IL}-1 \beta$-induced apoptosis in INS-1E cells and primary beta cells (Figure 4), and it is also a central mediator of apoptosis following ER stress in other cell types. ${ }^{37} \mathrm{CPA}+\mathrm{IL}-1 \beta$ exposure preferentially induces the expression of the Bims. Bim $\mathrm{S}$ is the most pro-apoptotic variant of Bim, as it lacks the dynein domain that

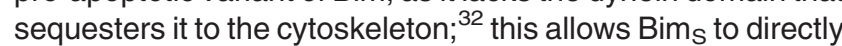
bind and activate Bax and Bak. In line with this, the preferential induction of Bim $\mathrm{S}$ is a key mechanism for apoptosis induced by B-RAF inhibitors in melanoma cells. ${ }^{38}$ Bim activation is not the sole mechanism by which mild ER stress predisposes beta cells to apoptosis. Thus, we have previously described that ER stress leads to $\mathrm{Mcl}-1$ degradation ${ }^{27}$ and have presently observed that even a mild ER stress triggers a progressive inhibition of $A 1$ expression. This contrasts with the observed increase in A1 mRNA expression induced by CPA. A similar phenomenon was observed with $\mathrm{Mcl}-1$, that is, an increase in mRNA accompanied by a decrease in protein expression. $^{27}$ This suggests that both $\mathrm{A} 1$ and $\mathrm{Mcl}-1$ are among the many proteins whose translation is inhibited by ER stress. $A 1$ is regulated at the post-translational level by phosphorylation, cleavage and proteasome-mediated degradation, ${ }^{39}$ which may further contribute to its progressive depletion during the UPR. As the four main anti-apoptotic proteins, namely $\mathrm{Bcl}-2, \mathrm{Bcl}-\mathrm{XL}, \mathrm{Mcl}-1$ and $\mathrm{A} 1$, are required to counteract the pro-apoptotic effects of Bim, a situation causing loss of any of these anti-apoptotic proteins will favor cell death. Here we demonstrate that ER stress in combination with an inflammatory cytokine leads to increased Bim and decreased A1 expression, culminating in beta cell death.

In conclusion, we presently demonstrated that the crosstalk between ER stress and the pro-inflammatory cytokine IL-1 $\beta$ sensitizes pancreatic beta cells to apoptosis mainly via an imbalance in the ratio of the anti-apoptotic $\mathrm{A} 1$ and the pro-apoptotic $\mathrm{BH} 3$-only protein $\mathrm{Bim}$. This combination of factors may lead beta cells to overreact to a mild inflammatory insult, leading to increased beta cell demise, augmented insulitis and, consequently, increased risk of clinical T1D.

\section{Materials and Methods}

Culture of INS-1E cells and primary rat beta cells. The rat insulinproducing INS-1E cell line (passages 60-70, a kind gift from Dr. C Wollheim, Centre Medical Universitaire, Geneva, Switzerland) was cultured in RPMI 1640 GlutaMAX-I (Invitrogen, Carlsbad, CA, USA) with 5\% heat-inactivated fetal bovine serum (FBS) and supplemented as described. ${ }^{40}$

Male Wistar rats (Charles River Laboratories, Brussels, Belgium) were housed and treated according to the Belgian Regulations for Animal Care guidelines. Rat pancreatic islets were isolated and pancreatic beta cells purified by fluorescenceactivated cell sorting (FACSAria, BD Bioscience, San Jose, CA, USA). ${ }^{41,42}$ The preparations used in this study contained $96 \pm 1 \%$ of beta cells $(n=7)$. Purified beta cells were cultured in Ham's F-10 medium containing $10 \mathrm{mM}$ glucose, $2 \mathrm{mM}$ GlutaMAX, $50 \mu \mathrm{M}$ 3-isobutyl-L-methylxanthine, $0.5 \%$ fatty acid-free BSA (Roche, Indianapolis, IN, USA), $5 \% \mathrm{FBS}, 50 \mathrm{U} / \mathrm{ml}$ penicillin and $50 \mu \mathrm{g} / \mathrm{ml}$ streptomycin. The same medium without FBS was used during the treatments described below.

Cell treatment. INS-1E cells and primary rat beta cells were exposed to $6.25 \mu \mathrm{M}$ CPA (Sigma-Aldrich, Steinheim, Germany), a concentration that induces 


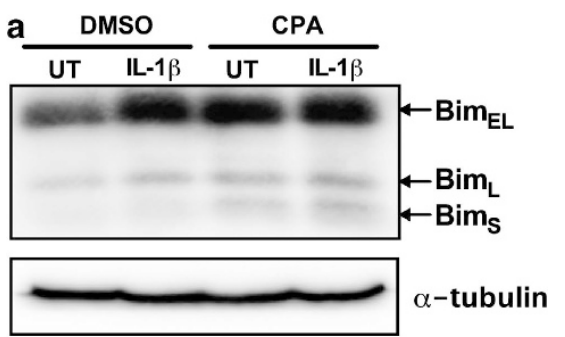

b

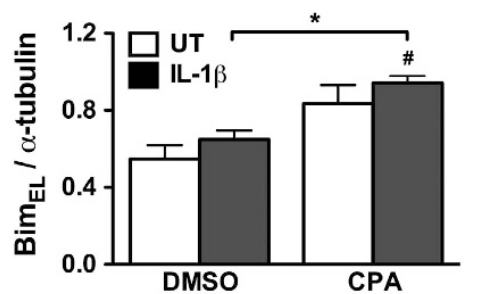

C

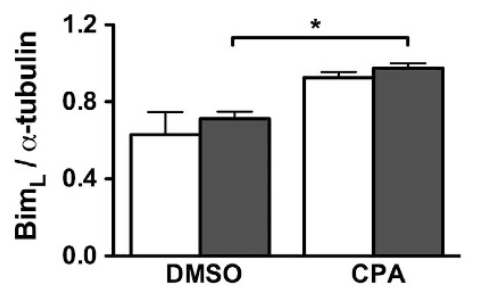

d

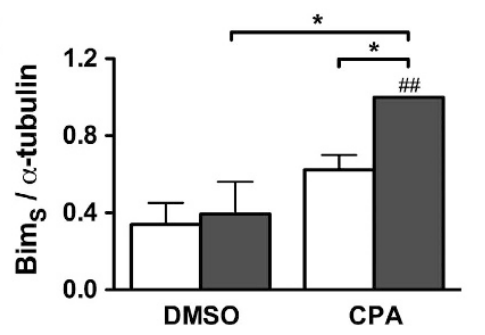

Figure 5 Augmented Bim expression correlates with increased beta cell apoptosis. INS-1E cells were exposed to CPA $(6.25 \mu \mathrm{M})$ or DMSO for $6 \mathrm{~h}$ and then treated with IL-1 $\beta(0.5 \mathrm{U} / \mathrm{ml})$ or left untreated (UT) for $24 \mathrm{~h}$. Cells were harvested for Bim western blot (a). Expression of (b) $B_{i m}$, (c) Bim and (d) Bim $\mathrm{S}_{\mathrm{S}}$ was quantified by densitometry and corrected by $\alpha$-tubulin. Results are the mean \pm S.E.M. of four independent experiments. ${ }^{\#} P<0.05$ and ${ }^{\# \#} P<0.01$ versus DMSO, ${ }^{*} P<0.05$ versus indicated bars; ANOVA

mild ER stress in these cells ${ }^{19,29}$ (Supplementary Figure 1). CPA was dissolved in dimethylsulfoxide (DMSO), which was used as control condition at the concentration of $0.03 \%$. Cells were incubated for $6 \mathrm{~h}$ with CPA or DMSO and then treated with IL-1 $\beta(0.5 \mathrm{U} / \mathrm{ml}$, R\&D Systems, Abingdon, UK) or left untreated. This combined treatment was previously shown to exacerbate the pro-inflammatory response. ${ }^{19}$ Alternatively, INS-1E cells were treated with $\mathrm{IL}-1 \beta+\mathrm{IFN}-\gamma$ (10 and $100 \mathrm{U} / \mathrm{ml}$, respectively, R\&D Systems) or left untreated. These cytokine concentrations were selected based on previous time-course and dose-response analyses. ${ }^{31,43}$

mRNA extraction and real-time RT-PCR. INS-1E cells and rat primary beta cells were lysed and harvested for mRNA extraction and reverse transcribed as described. ${ }^{42}$ Gene expression was evaluated by real-time RT-PCR using SYBR Green. ${ }^{42}$ Standard primers were used to construct a curve of cDNA with known copy numbers, to which unknown samples were compared. ${ }^{44}$ Expression values were corrected by the housekeeping gene GAPDH (glyceraldehyde-3-phosphate dehydrogenase) and normalized by the highest value of each experiment (considered as 1). GAPDH expression is not altered by the treatments used ${ }^{45-47}$ (data not shown). The primers used for this study are described in Supplementary Table 1.
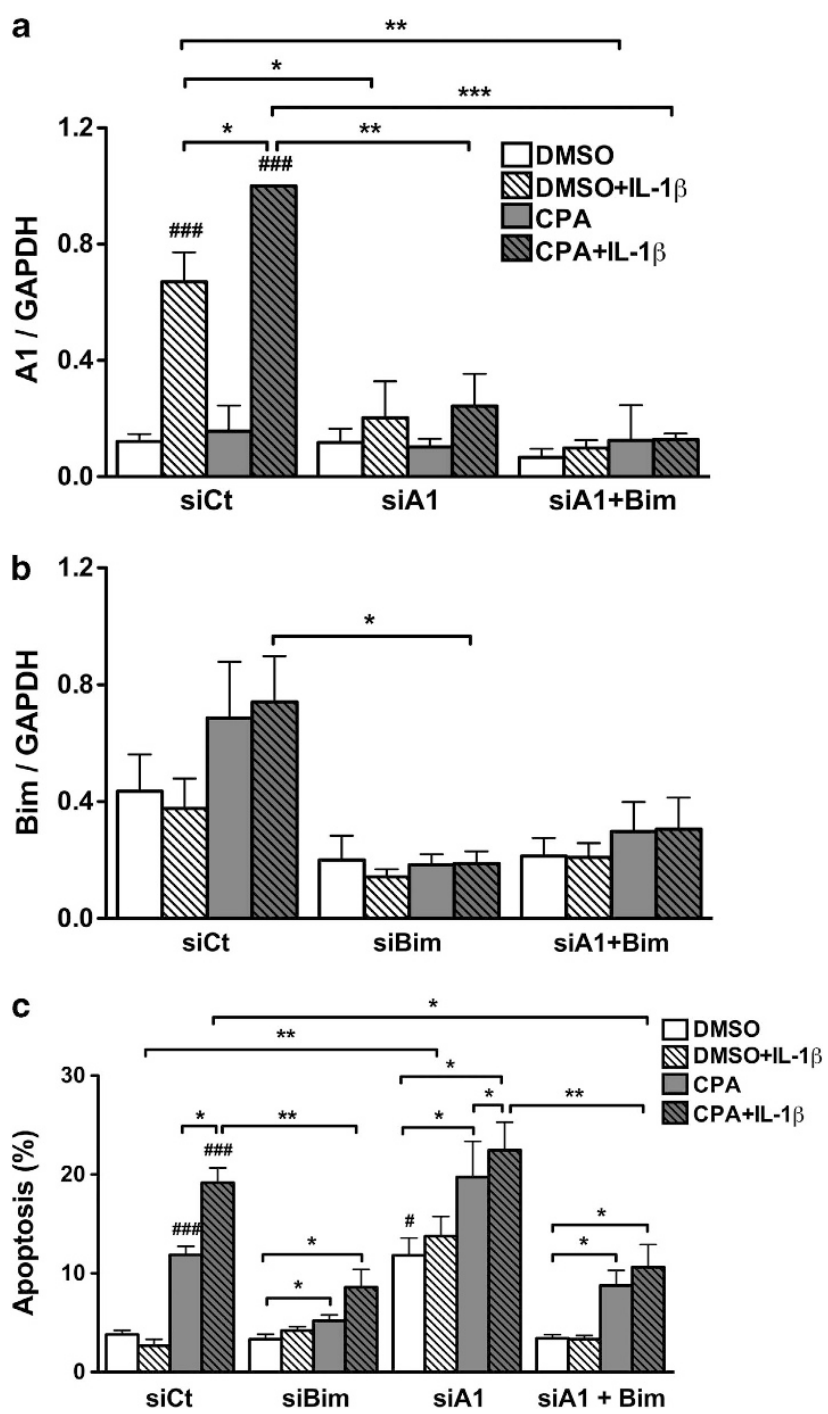

Figure 6 Bim KD protects against beta cell apoptosis induced by inactivation of $\mathrm{A} 1$ and CPA + IL-1 $\beta$ treatment. INS-1E cells were transfected with siRNA against A1 (siA1) alone or together with siRNA against Bim (siBim), or with negative control siRNA (siCt). After $48 \mathrm{~h}$, cells were incubated with CPA $(6.25 \mu \mathrm{M})$ or DMSO for $6 \mathrm{~h}$ and then treated or not with $\mathrm{IL}-1 \beta(0.5 \mathrm{U} / \mathrm{ml})$ for $24 \mathrm{~h}$. Cells were harvested to determine A1 (a) and Bim (b) mRNA expression, which was corrected by the housekeeping gene GAPDH. (c) Beta cell apoptosis was evaluated by Hoechst $33342 / \mathrm{PI}$ staining. Results are the mean \pm S.E.M. of five independent experiments. ${ }^{\#} P<0.05$ and ${ }^{\# \# \#} P<0.001$ versus siCt + DMSO, ${ }^{*} P<0.05$, ${ }^{* *} P<0.01$ and ${ }^{* \star *} P<0.001$ versus indicated bars; paired $t$-test

Small interfering RNA (siRNA) transfection. Specific siRNAs were used to silence XBP1 ${ }^{48} \mathrm{Bim},{ }^{21,24} \mathrm{Bcl}-2, \mathrm{Bcl}-\mathrm{XL},{ }^{23} \mathrm{~A} 1$ (Invitrogen) ${ }^{28}$ and $\mathrm{Mcl}-1$ (Thermo Scientific, Chicago, IL, USA). ${ }^{25,27}$ These siRNAs have been previously tested and validated by our group, including confirmation of findings with a second siRNA. ${ }^{21,23-25,27}$ An overnight transfection was performed with $30 \mathrm{nM}$ siRNA mixed with Lipofectamine RNAiMAX (Invitrogen) as described. ${ }^{26,49}$ Allstars Negative Control siRNA (Qiagen, Venlo, The Netherlands) was used as a negative control. We have previously shown that transfection with this control siRNA does not affect beta cell function, gene expression or viability as compared with nontransfected cells. ${ }^{47,48,50}$

Apoptosis assays. INS-1E cells and rat primary beta cells were incubated with the DNA dyes Hoechst 33342 (10 and $20 \mu / / m l$, respectively) and propidium iodide (PI, $10 \mu / / \mathrm{ml})$ for $15 \mathrm{~min}$. Beta cell viability was evaluated in at least 500 

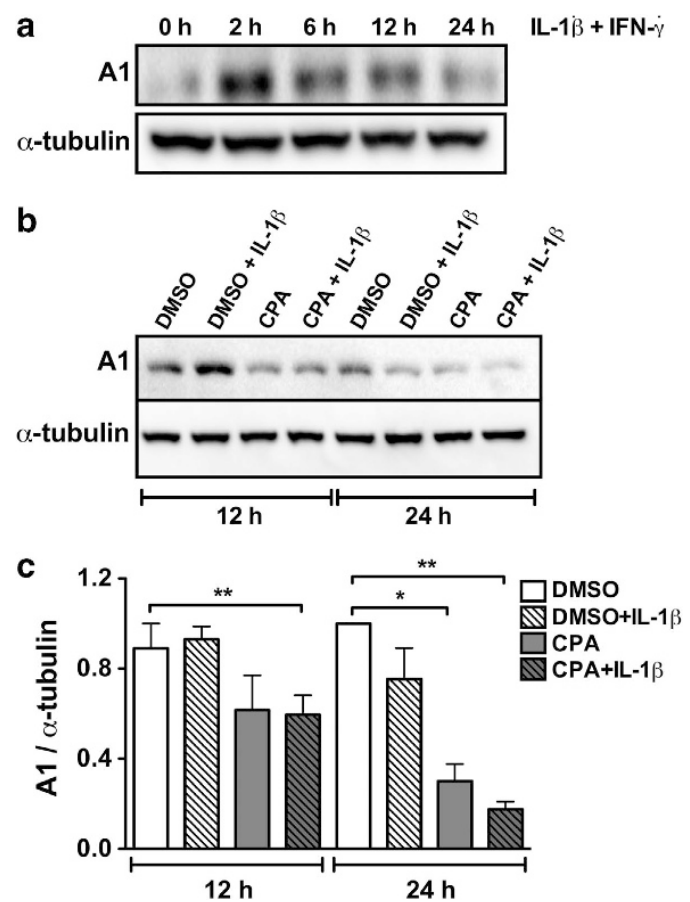

Figure $7 \mathrm{CPA}$ and IL-1 $\beta$ progressively decrease A1 expression. (a) INS-1E cells were treated with IL-1 $\beta+\mathrm{IFN}-\gamma$ (10 and $100 \mathrm{U} / \mathrm{ml}$, respectively) for the indicated time points. (b) INS-1E were pretreated with CPA $(6.25 \mu \mathrm{M})$ or DMSO for $6 \mathrm{~h}$ and then exposed or not to $\mathrm{IL}-1 \beta(0.5 \mathrm{U} / \mathrm{ml})$ for the indicated time points. Cells were harvested and $\mathrm{A} 1$ and $\alpha$-tubulin protein expression was determined by western blot. (c) A1 expression was quantified by densitometry and corrected by $\alpha$-tubulin. Results are the mean \pm S.E.M. of three independent experiments. ${ }^{*} P<0.05$ and ${ }^{* *} P<0.01$ versus indicated bars, paired $t$-test

cells per condition by two observers, one of them unaware of the sample identity. ${ }^{42,51}$ In some experiments, presence of apoptosis was confirmed by examining expression of cleaved caspases 9 and 3 (see below).

Western blot. INS-1E cells were lysed and collected in Laemmli buffer. Whole-cell lysates were resolved by $10-14 \%$ SDS-PAGE, transferred to nitrocellulose membrane and immunoblotted with antibodies targeting cleaved caspase 9, cleaved caspase 3, Bim, Bcl-XL, Bcl-2 (Cell Signaling, Danvers, MA, USA), Mcl-1 (Biovision, Milpitas, CA, USA) and A1 (Abcam, Cambridge, UK); $\alpha$-tubulin was used as a control for protein loading (Sigma-Aldrich). Anti-rabbit or anti-mouse horseradish peroxidase-labeled anti-lgG (Lucron Bioproducts, De Pinte, Belgium) was used as secondary antibody. Immunoreactive protein bands were revealed using a chemiluminescent substrate (SuperSignal West Femto, Thermo Scientific), detected by ChemiDoc XRS ${ }^{+}$and quantified with ImageLab software (Bio-Rad, Hercules, CA, USA).

Statistical analysis. Data are presented as mean \pm S.E.M. Comparisons were performed by two-tailed paired Student's $t$-test or by ANOVA, followed by Student's $t$-test with Bonferroni correction as indicated. A $P$-value $<0.05$ was considered statistically significant.

\section{Conflict of Interest}

The authors declare no conflict of interest.

Acknowledgements. We thank the personnel from the Laboratory of Experimental Medicine, I Millard, S Mertens, A Musuaya and M Pangerl for excellent technical support. This work was supported by grants from the Fonds National de la Recherche Scientifique (FNRS), Belgium, the Communauté Française de Belgique-Actions de Recherche Concertées (ARC), the European Union (projects Naimit and BetaBat, in the Framework Programme
7 of the European Community), the Juvenile Diabetes Foundation International (JDFI) and the Expert Center Grant 2008.40.001 from the Dutch Diabetes Research Foundation. MLC was the recipient of a scholarship from CAPES (Brazilian Coordination for the Improvement of Higher Education Personnel). Dr. Décio L Eizirik is the guarantor of this work, had full access to all the data and took full responsibility for the integrity of data and the accuracy of data analysis.

1. Eizirik $\mathrm{DL}$, Colli $\mathrm{ML}$, Ortis $\mathrm{F}$. The role of inflammation in insulitis and $\beta$-cell loss in type 1 diabetes. Nat Rev Endocrinol 2009; 5: 219-226.

2. Ziegler AG, Nepom GT. Prediction and pathogenesis in type 1 diabetes. Immunity 2010; 32: $468-478$.

3. Patterson CC, Dahlquist GG, Gyurus E, Green A, Soltesz G. Incidence trends for childhood type 1 diabetes in Europe during 1989-2003 and predicted new cases 2005-20: a multicentre prospective registration study. Lancet 2009; 373: 2027-2033.

4. Van Belle TL, Coppieters KT, von Herrath MG. Type 1 diabetes: etiology, immunology, and therapeutic strategies. Physiol Rev 2011; 91: 79-118.

5. Knip M, Veijola R, Virtanen SM, Hyoty H, Vaarala O, Akerblom HK. Environmental triggers and determinants of type 1 diabetes. Diabetes 2005; 54(Suppl 2): S125-S136.

6. Carlsson A, Kockum I, Lindblad B, Engleson L, Nilsson A, Forsander G et al. Low risk HLA-DQ and increased body mass index in newly diagnosed type 1 diabetes children in the Better Diabetes Diagnosis study in Sweden. Int J Obes (Lond) 2011; 36: 718-724

7. Cnop M, Foufelle F, Velloso LA. Endoplasmic reticulum stress, obesity and diabetes. Trends Mol Med 2012; 18: 59-68.

8. Eizirik DL, Miani M, Cardozo AK. Signalling danger: endoplasmic reticulum stress and the unfolded protein response in pancreatic islet inflammation. Diabetologia 2013; 56: 234-241.

9. Eizirik DL, Cardozo AK, Cnop M. The role for endoplasmic reticulum stress in diabetes mellitus. Endocr Rev 2008; 29: 42-61.

10. Eizirik DL, Cnop M. ER stress in pancreatic $\beta$-cells: the thin red line between adaptation and failure. Sci Signal 2010; 3: pe7.

11. Walter $P$, Ron $D$. The unfolded protein response: from stress pathway to homeostatic regulation. Science 2011; 334: 1081-1086

12. Gurzov EN, Eizirik DL. Bcl-2 proteins in diabetes: mitochondrial pathways of $\beta$-cell death and dysfunction. Trends Cell Biol 2011; 21: 424-431.

13. Fonseca SG, Gromada J, Urano F. Endoplasmic reticulum stress and pancreatic $\beta$-cell death. Trends Endocrinol Metab 2011; 22: 266-274.

14. Cardozo AK, Ortis F, Storling J, Feng YM, Rasschaert J, Tonnesen M et al. Cytokines downregulate the sarcoendoplasmic reticulum pump $\mathrm{Ca}^{2+}$ ATPase $2 \mathrm{~b}$ and deplete endoplasmic reticulum $\mathrm{Ca}^{2+}$, leading to induction of endoplasmic reticulum stress in pancreatic $\beta$-cells. Diabetes 2005; 54: 452-461.

15. Akerfeldt MC, Howes J, Chan JY, Stevens VA, Boubenna N, McGuire HM et al. Cytokineinduced $\beta$-cell death is independent of endoplasmic reticulum stress signaling. Diabetes 2008; 57: 3034-3044.

16. Allagnat F, Fukaya M, Nogueira TC, Delaroche D, Welsh N, Marselli $L$ et al. C/EBP homologous protein contributes to cytokine-induced pro-inflammatory responses and apoptosis in $\beta$-cells. Cell Death Differ 2012; 19: 1836-1846.

17. Tersey SA, Nishiki Y, Templin AT, Cabrera SM, Stull ND, Colvin SC et al. Islet $\beta$-cell endoplasmic reticulum stress precedes the onset of type 1 diabetes in the nonobese diabetic mouse model. Diabetes 2012; 61: 818-827.

18. Marhfour I, Lopez XM, Lefkaditis D, Salmon I, Allagnat F, Richardson SJ et al. Expression of endoplasmic reticulum stress markers in the islets of patients with type 1 diabetes. Diabetologia 2012; 55: 2417-2420.

19. Miani M, Colli ML, Ladriere L, Cnop M, Eizirik DL. Mild endoplasmic reticulum stress augments the proinflammatory effect of IL- $1 \beta$ in pancreatic rat $\beta$-cells via the IRE $1 \alpha / \mathrm{XBP} 1 \mathrm{~s}$ pathway. Endocrinology 2012; 153: 3017-3028

20. Youle RJ, Strasser A. The BCL-2 protein family: opposing activities that mediate cell death. Nat Rev Mol Cell Biol 2008; 9: 47-59.

21. Barthson J, Germano CM, Moore F, Maida A, Drucker DJ, Marchetti $P$ et al. Cytokines TNF- $\alpha$ and IFN- $\gamma$ induce pancreatic $\beta$-cell apoptosis through STAT1-mediated Bim protein activation. J Biol Chem 2011; 286: 39632-39643.

22. Gurzov EN, Ortis F, Cunha DA, Gosset G, Li M, Cardozo AK et al. Signaling by $\mathrm{IL}-1 \beta+\mathrm{IFN}-\gamma$ and ER stress converge on DP5/Hrk activation: a novel mechanism for pancreatic $\beta$-cell apoptosis. Cell Death Differ 2009; 16: 1539-1550.

23. Gurzov EN, Germano CM, Cunha DA, Ortis F, Vanderwinden JM, Marchetti P et al. p53 up-regulated modulator of apoptosis (PUMA) activation contributes to pancreatic $\beta$-cell apoptosis induced by proinflammatory cytokines and endoplasmic reticulum stress. J Biol Chem 2010; 285: 19910-19920.

24. Santin I, Moore F, Colli ML, Gurzov EN, Marselli L, Marchetti P et al. PTPN2, a candidate gene for type 1 diabetes, modulates pancreatic $\beta$-cell apoptosis via regulation of the BH3-only protein Bim. Diabetes 2011; 60: 3279-3288.

25. Colli ML, Nogueira TC, Allagnat F, Cunha DA, Gurzov EN, Cardozo AK et al. Exposure to the viral by-product dsRNA or Coxsackievirus $\mathrm{B} 5$ triggers pancreatic $\beta$-cell apoptosis via a Bim/Mcl-1 imbalance. PLoS Pathog 2011; 7: e1002267. 
26. Moore F, Santin I, Nogueira TC, Gurzov EN, Marselli L, Marchetti P et al. The transcription factor C/EBP $\delta$ has anti-apoptotic and anti-inflammatory roles in pancreatic $\beta$-cells. PLoS One 2012; 7: e31062.

27. Allagnat F, Cunha D, Moore F, Vanderwinden JM, Eizirik DL, Cardozo AK. Mcl-1 downregulation by pro-inflammatory cytokines and palmitate is an early event contributing to $\beta$-cell apoptosis. Cell Death Differ 2011; 18: 328-337.

28. Eizirik DL, Sammeth M, Bouckenooghe T, Bottu G, Sisino G, Igoillo-Esteve M et al. The human pancreatic islet transcriptome: expression of candidate genes for type 1 diabetes and the impact of pro-inflammatory cytokines. PLoS Genet 2012; 8: e1002552.

29. Pirot $P$, Eizirik DL, Cardozo AK. IFN- $\gamma$ potentiates endoplasmic reticulum stress-induced death by reducing pancreatic $\beta$-cell defence mechanisms. Diabetologia 2006; 49: 1229-1236.

30. Pirot P, Naamane N, Libert F, Magnusson NE, Orntoft TF, Cardozo AK et al. Global profiling of genes modified by endoplasmic reticulum stress in pancreatic $\beta$-cells reveals the early degradation of insulin mRNAs. Diabetologia 2007; 50: 1006-1014.

31. Eizirik DL, Mandrup-Poulsen T. A choice of death: the signal-transduction of immunemediated $\beta$-cell apoptosis. Diabetologia 2001; 44: 2115-2133.

32. O'Connor L, Strasser A, O'Reilly LA, Hausmann G, Adams JM, Cory S et al. Bim: a novel member of the Bcl-2 family that promotes apoptosis. EMBO J 1998; 17: 384-395.

33. Tang C, Naassan AE, Chamson-Reig A, Koulajian K, Goh TT, Yoon F et al. Susceptibility to fatty acid-induced $\beta$-cell dysfunction is enhanced in prediabetic diabetes-prone biobreeding rats: a potential link between $\beta$-cell lipotoxicity and islet inflammation. Endocrinology 2013; 154: 89-101.

34. Oslowski CM, Hara T, O'Sullivan-Murphy B, Kanekura K, Lu S, Hara M et al. Thioredoxininteracting protein mediates ER stress-induced $\beta$ cell death through initiation of the inflammasome. Cell Metab 2012; 16: 265-273.

35. Lerner AG, Upton JP, Praveen PV, Ghosh R, Nakagawa Y, Igbaria A et al. IRE $1 \alpha$ induces thioredoxin-interacting protein to activate the NLRP3 inflammasome and promote programmed cell death under irremediable ER stress. Cell Metab 2012; 16: 250-264.

36. Edlich F, Banerjee S, Suzuki M, Cleland MM, Arnoult D, Wang C et al. Bcl-x(L) retrotranslocates Bax from the mitochondria into the cytosol. Cell 2011; 145: 104-116.

37. Puthalakath H, O'Reilly LA, Gunn P, Lee L, Kelly PN, Huntington ND et al. ER stress triggers apoptosis by activating BH3-only protein Bim. Cell 2007; 129: 1337-1349.

38. Jiang CC, Lai F, Tay KH, Croft A, Rizos H, Becker TM et al. Apoptosis of human melanoma cells induced by inhibition of B-RAFV600E involves preferential splicing of bimS. Cell Death Dis 2010; 1: e69.

39. Vogler M. BCL2A1: the underdog in the BCL2 family. Cell Death Differ 2012; 19: 67-74.

40. Asfari M, Janjic D, Meda P, Li G, Halban PA, Wollheim CB. Establishment of 2-mercaptoethanol-dependent differentiated insulin-secreting cell lines. Endocrinology 1992; 130: 167-178.
41. Pipeleers DG, in't Veld PA, Van de Winkel M, Maes E, Schuit FC, Gepts W. A new in vitro model for the study of pancreatic $\alpha$ and $\beta$ cells. Endocrinology 1985; 117: 806-816.

42. Rasschaert J, Ladriere L, Urbain M, Dogusan Z, Katabua B, Sato S et al. Toll-like receptor 3 and STAT-1 contribute to double-stranded RNA + IFN- $\gamma$-induced apoptosis in primary pancreatic $\beta$-cells. J Biol Chem 2005; 280: 33984-33991.

43. Kutlu B, Cardozo AK, Darville MI, Kruhoffer M, Magnusson N, Orntoft T et al. Discovery of gene networks regulating cytokine-induced dysfunction and apoptosis in insulin-producing INS-1 cells. Diabetes 2003; 52: 2701-2719.

44. Overbergh L, Valckx D, Waer M, Mathieu C. Quantification of murine cytokine mRNAs using real time quantitative reverse transcriptase PCR. Cytokine 1999; 11 305-312.

45. Cardozo AK, Kruhoffer M, Leeman R, Orntoft T, Eizirik DL. Identification of novel cytokineinduced genes in pancreatic $\beta$-cells by high-density oligonucleotide arrays. Diabetes 2001; 50: 909-920.

46. Liu D, Darville M, Eizirik DL. Double-stranded ribonucleic acid (RNA) induces $\beta$-cell Fas messenger RNA expression and increases cytokine-induced $\beta$-cell apoptosis. Endocrinology 2001; 142: 2593-2599.

47. Moore F, Colli ML, Cnop M, Esteve MI, Cardozo AK, Cunha DA et al. PTPN2, a candidate gene for type 1 diabetes, modulates IFN- $\gamma$-induced pancreatic $\beta$-cell apoptosis. Diabetes 2009; 58: 1283-1291.

48. Allagnat $F$, Christulia F, Ortis F, Pirot $P$, Lortz $S$, Lenzen $S$ et al. Sustained production of spliced X-box binding protein 1 (XBP1) induces pancreatic $\beta$-cell dysfunction and apoptosis. Diabetologia 2010; 53: 1120-1130.

49. Moore F, Cunha DA, Mulder H, Eizirik DL. Use of RNA interference to investigate cytokine signal transduction in pancreatic $\beta$-cells. Methods Mol Biol 2012; 820: 179-194.

50. Moore F, Naamane N, Colli ML, Bouckenooghe T, Ortis F, Gurzov EN et al. STAT1 is a master regulator of pancreatic $\beta$-cell apoptosis and islet inflammation. J Biol Chem 2011; 286: 929-941.

51. Ortis F, Cardozo AK, Crispim D, Storling J, Mandrup-Poulsen T, Eizirik DL. Cytokineinduced pro-apoptotic gene expression in insulin-producing cells is related to rapid sustained and non-oscillatory NF-KB activation. Mol Endocrinol 2006; 20: 1867-1879.

(c) (i) (2) (2) Cell Death and Disease is an open-access journal cc. licensed under a Creative Commons Attribution-NonCommercialShareAlike 3.0 Unported License. To view a copy of this license, visit http://creativecommons.org/licenses/by-nc-sa/3.0/

Supplementary Information accompanies this paper on Cell Death and Disease website (http://www.nature.com/cddis) 